OPEN ACCESS

Edited by:

Lin Chen,

PLA General Hospital, China

Reviewed by:

Zhao-lei Zeng,

Sun Yat-sen University Cancer

Center, China

Ying Yuan,

Zhejiang University, China

*Correspondence:

Bin Xiong

binxiong1961@whu.edu.cn

†These authors have contributed equally to this work

Specialty section:

This article was submitted to Gastrointestinal Cancers, a section of the journal

Frontiers in Oncology

Received: 20 August 2019 Accepted: 29 November 2019 Published: 13 December 2019

Citation:

Yang $C$, Chen F, Wang S and Xiong B (2019) Circulating Tumor Cells in Gastrointestinal Cancers: Current Status and Future Perspectives. Front. Oncol. 9:1427. doi: 10.3389/fonc.2019.01427

\section{Circulating Tumor Cells in Gastrointestinal Cancers: Current Status and Future Perspectives}

\author{
Chaogang Yang ${ }^{1,2,3 t}$, Fangfang Chen ${ }^{2,3,44}$, Shuyi Wang ${ }^{1,2,3}$ and Bin Xiong ${ }^{1,2,3 *}$ \\ ${ }^{1}$ Department of Gastrointestinal Surgery, Zhongnan Hospital of Wuhan University, Wuhan, China, ${ }^{2}$ Hubei Key Laboratory of \\ Tumor Biological Behaviors, Wuhan, China, ${ }^{3}$ Hubei Cancer Clinical Study Center, Wuhan, China, ${ }^{4}$ Department of Breast and \\ Thyroid Surgery, Zhongnan Hospital of Wuhan University, Wuhan, China
}

Circulating tumor cells (CTCs), which are now defined as the "break away" cancer cells that derive from primary- or metastatic-tumor sites and present in the bloodstream, are considered to be the precursors of metastases. Considering the key role of CTCs in cancer progression, researchers are committed to analyze them in the past decades and many technologies have been proposed for achieving CTCs isolation and characterization with highly sensitivity and specificity until now. On this basis, clinicians gradually realize the clinical values of CTCs' detection through various clinical studies. As a "liquid biopsy," CTCs' detection and measurement can supply important information for predicting patient's survival, monitoring of response/resistance, assessment of minimal residual disease, evaluating distant metastasis, and sometimes, customizing therapy choices. Nowadays, eliminating CTCs of the blood circulation has been regarded as a promising method to prevent tumor metastasis. However, research on CTCs still faces many challenges. Herein, we present an overview to discuss the current concept of CTCs, summarize the available techniques for CTCs detection, and provide an update on the clinical significance of CTCs in gastrointestinal malignancies, especially focus on gastric and colorectal cancer.

Keywords: circulating tumor cells, gastric cancer, colorectal cancer, detection, identification, clinical application

\section{INTRODUCTION}

According to the GLOBOCAN 2018 reports, cancer is estimated to rank as the leading cause of death worldwide (1). Gastrointestinal (GI) malignancies, an important component of solid tumors, bear a heavier cancer-associated burden (2). At present, metastasis remains the main cause for GI malignancy-related deaths (3). Even for the early-stage patients who underwent curative resection, a considerable portion suffer metastatic disease within 5 years of surgery (4). This evidence implies that an occult metastatic process is parallel with primary tumor development (5) or that tumor cells with metastatic potential have entered the bloodstream from the primary tumor site during surgery and cause subsequent distant metastasis in the aforementioned patients (6). These cells are termed circulating tumor cells (CTCs), which have been proposed to be the important mediators of hematogenous metastasis of solid malignant tumors $(6,7)$.

CTCs, first reported by Ashworth in 1869 and further demonstrated by Engell in 1955, are now defined as the "break away" cancer cells that derive from primary or metastatic tumor sites and present in the blood circulation (8). These cells shed intermittently from the tumor site, circulate 
within the bloodstream, potentially seed into distant organs and finally form vital metastases (8). Therefore, research on CTCs can provide more insights into metastasis-associated progression. However, the extremely low concentration in the peripheral blood (one CTC in millions of blood cells) makes CTCs detection a technical challenge (9), which in turn greatly limits in-depth studies on the biological properties of CTCs (10). Nevertheless, given the critical role of CTCs in tumor progression, many researchers have expended much effort to explore efficiently capture CTCs (9). Consequently, a considerable amount of scientific literature has published over the past decade, occurring in parallel with technical progress that has propelled this field forward. To date, a number of technologies based on the biological or physical properties of CTCs have been developed for achieving CTCs isolation and identification $(9,11-13)$, which lay the technical foundation for conducting more clinical research to explore the clinical value of CTCs detection in predicting patient survival, customizing therapy choices, monitoring response/resistance, and evaluating distant metastasis in numerous types of cancer (14). Over the past few years, our group has been working on CTCs detection methods and has developed a variety of methods based on the different biophysical characteristics of CTCs (15-24); these studies have enabled us to efficiently capture CTCs in the peripheral blood and to further analyze the prognostic value of quantitative and qualitative CTCs analysis in gastrointestinal (GI) malignancies (25-27).

In this review, we aim to outline the current status of CTCs detection techniques, the clinical implications, and the limitations and opportunities in GI cancers, including gastric cancer (GC) and colorectal cancer (CRC); we then provide new insights into the applications of CTCs detection to guide clinical practice.

\section{ISOLATION AND ENRICHMENT TECHNOLOGIES OF CTCS}

Although the primary tumor or metastasis site releases tumor cells into the blood at all times, most of them are eliminated by the body's immune system, and only a few CTCs survives in the blood circulation. Therefore, the number of CTCs is sparse ( $\sim 1$ CTC per $\mathrm{ml}$ of blood) compared to the number of other cellular components in the peripheral blood (5). This situation poses a high technical challenge for us to accurately isolate CTCs from millions of blood cells, indicating that an ideal technology for CTCs separation needs to have the following characteristics: (1) the ability to isolate all heterogeneous CTCs; (2) the ability to exclude the background interference caused by normal blood cells; and (3) the ability to accurately identify all candidate CTCs. At present, it has been well-recognized that the biological and physical characteristics of CTCs are obviously different from those of other cells in the blood (8). Consequently, many capture and identification technologies based on different CTCs features are gradually being developed to pursue the ultimate goal of achieving CTCs enrichment with high specificity and sensitivity $(9,11-13)$. For CTC enrichment, the isolation of CTCs is usually the first step, and the characterization of CTCs (the second step) further distinguishes the CTCs from the remaining normal blood cells. As shown in Figure 1, we presented an overview of the technologies utilized for CTCs isolation and characterization, and these technologies are commonly used in GC and CRC.

\section{Immunoaffinity-Based Technologies of CTCs}

Immunoaffinity-based technologies, including positive or negative selection assays, achieve CTCs isolation with an antibody-immobilized inert surface combined with magnetic beads (28). Among these assays, positive selection assays frequently rely on two types of antigens, either single or a combination, that include the epithelial- or tumor-specific cell surface antigens (12). In the process of GC- and CRC-CTCs isolation, the most commonly used epithelial-specific cell surface antigens are cytokeratins (CKs) 18, 19, 20 and epithelial cell adhesion molecules (EpCAMs). CKs are intermediate filament keratins found in the cytoskeletons of epithelial cells (29). EpCAM is a human cell surface glycoprotein involved in cell-tocell adhesion, which overexpresses in epithelial cancers and has been extensively used in proof-of-concept studies (30). Among tumor-specific cell surface antigens, carcinoembryonic antigen (CEA) has been largely utilized to isolate CRC-CTCs (31), and human epithelial growth factor receptor-2 (HER-2) was used for GC-CTCs isolation (32). Currently, several platforms, such as the CellSearch ${ }^{\circledR}$ System and AdnaTest ${ }^{\circledR}$ kit, have been developed for GC- and CRC-CTCs detection based on positive selection, and are now have achieved for commercially available $(27,33)$. Conversely, negative selection assays generally remove white blood cells (WBCs) from blood samples by targeting leukocyte surface-specific antigens (e.g., CD45 and CD61) that are not expressed in CTCs to achieve GC- and CRC-CTCs enrichment; the kits and techniques include the EasySep ${ }^{\circledR}$ Human CD45 Depletion Kit (34) and MACS ${ }^{\circledR}$ (35). Notably, Nagrath et al. developed the "CTC-Chip" platform by combining microfluidic technology with positive selection methods 10 years ago, and this method was able to selectively and efficiently isolate CTCs from whole blood using anti-EpCAM-coated posts with this microfluidic chip (36). Microfluidic devices are promising technologies for CTC isolation, which allow the separation of CTCs from small fluid volumes under laminar flow and eliminate the need for pre-labeling or sample processing (32). The Isoflux ${ }^{\circledR}$ System (Fluxion Biosciences Inc., South San Francisco, CA) was another classic automated EpCAM-based immunoaffinity functionalized microfluidic system that used immunomagnetic beads to facilitate the use of single or multiple capture antibodies to target cells of a specific pathology, providing near-perfect isolation efficiency (37). Although, given that there are no $100 \%$ tumor-specific antibodies, the false-positive (specificity) and false-negative (sensitivity) of CTCs isolation continue to impose shackles on immuno-magnetic detection techniques.

Among the commercially available semiautomated devices, the CellSearch ${ }^{\circledR}$ System (Veridex LLC, Raritan, NJ, USA) is the most reported immunoaffinity (EpCAM-based) method for CTCs isolation and counting, which has been approved by 


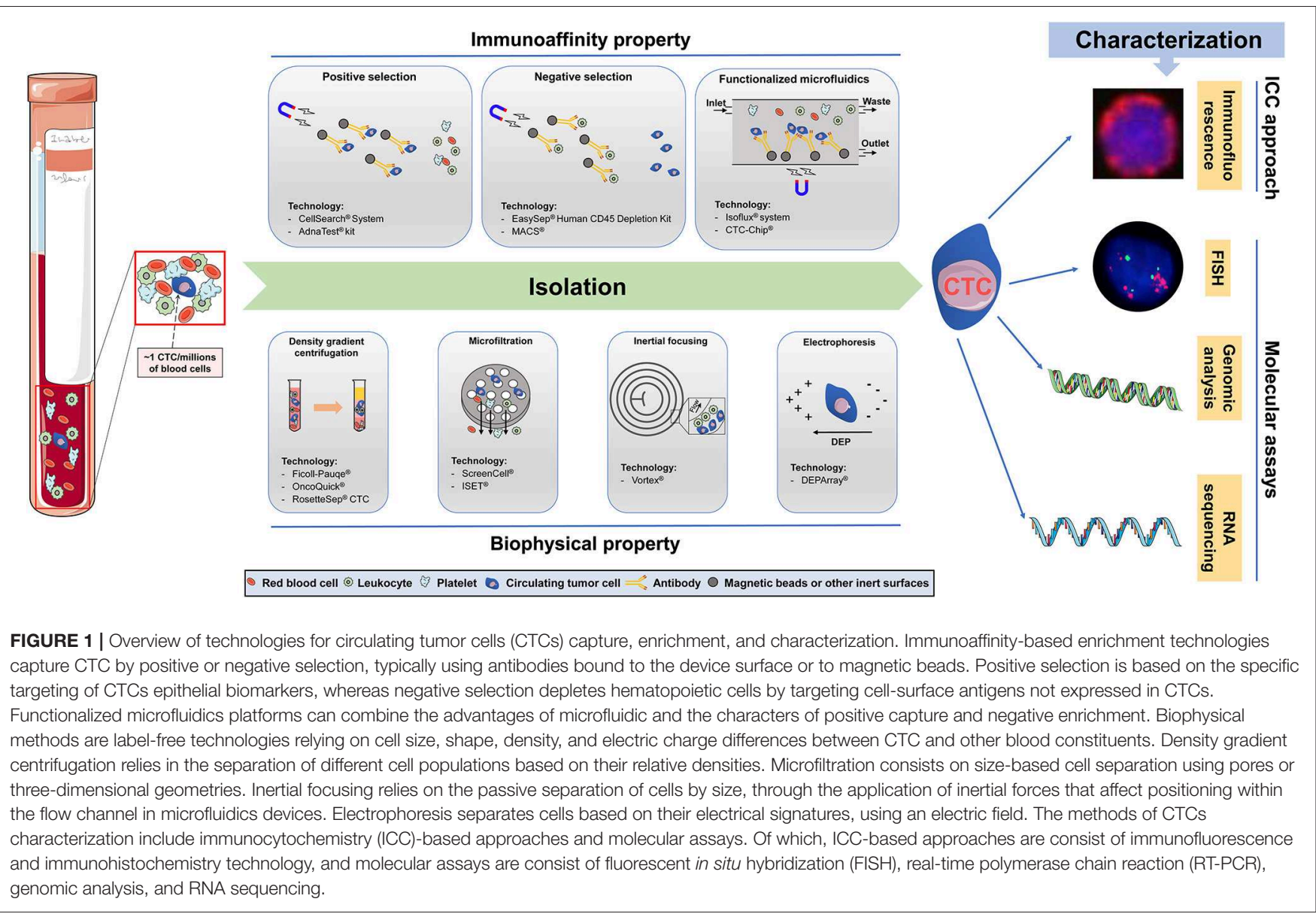

the Federal Drug And Food Administration (FDA) for use in metastatic breast and colon cancer patients (38). Additionally, it has also been widely used in the capture of GC and CRC-CTCs in recent years $(27,31)$. As one of the immunoaffinity assays, the major advantages of the CellSearch ${ }^{\circledR}$ System are the direct visualization and quantification of CTCs and the detection of living cells without the need for cell lysis. However, there is a nonnegligible fact that CellSearch detects a relatively low number of CTCs from the peripheral blood of patients with cancer, and this low sensitivity may be because the system captures solely EpCAM-positive CTCs that are significantly reduced or absent in certain CTCs subpopulations, especially for those undergoing epithelial-to-mesenchymal transition (EMT); this characteristic is still considered a major pitfall of this device (38).

Previously, our group also reported several immunoaffinitybased technologies for CTCs detection. First, we developed a new CTCs detection platform by using an electrospun $\mathrm{TiO} 2$ nanofiber-deposited substrate grafted with anti-EpCAM, which achieved high efficiency in CTCs detection from the blood of GC and CRC patients (15). Meanwhile, a new CTCs capture platform based on the transparent and biocompatible $\mathrm{TiO} 2$ nanoparticle spin coated on a glass substrate conjugated with anti-EpCAM also was successfully used to capture GC- and CRC-CTCs (16, 17). However, preparation of the above nanostructures requires either specialized equipment or complex process control, which limits its high-throughput fabrication. Moreover, the nontransparent nature makes them incompatible with many optical imaging systems (such as immunocytochemical techniques), which also constrains further application. Therefore, our group further used a hydroxyapatite/chitosan (HA/CTS) material as a nano-substrate, which was characterized by transparency and excellent biological compatibility, and conjugated this material with anti-EpCAM to develop simple but efficient CTCs detection platforms $(18,22)$. More importantly, the enumeration of CTCs by these platforms in GC patients could predict the clinical response to anticancer therapy (19). Furthermore, we coated anti-CD45 and anti-EpCAM onto the surface of the above nano-substrate to develop a combined negative and positive enrichment assay, exhibiting equally high capture efficiency and excellent purity for CRC-CTCs detection (21).

\section{Biophysical Property-Based Technologies of CTCs}

Considering the bias and narrow capture spectrum presented by the aforementioned immunoaffinity-based approaches in CTCs isolation, researchers began to develop a variety of CTCs isolation technologies based on the biophysical properties of CTCs to achieve a wide-scale and high-performance capture of CTCs (39). Biophysical CTCs enrichment technologies, characterized as "label-free," isolate CTCs from the blood based 
on the biophysical property differences, such as density, size, deformability, and electrical charge, that present among CTCs and other blood cells for CTCs separation and capture (40). Recently, there have been commercially available reagents and platforms based on the above different principles for separating GC- and CRC-CTCs, including density gradient centrifugation (Ficoll-Pauqe ${ }^{\circledR}$; OncoQuick ${ }^{\circledR}$; RosetteSep ${ }^{\circledR}$ CTC), microfiltration $\left(\right.$ ScreenCell ${ }^{\circledR}$; ISET ${ }^{\circledR}$ ), inertial focusing (Vortex ${ }^{\circledR}$ ), and electrophoresis (DEPArray ${ }^{\circledR}$ ) (41). The most common biophysical CTCs enrichment technology is size-based microfiltration, which assumes that CTCs can be isolated from blood cells due to their larger volume and more rigid shape, and this technology has been improved by the introduction of nano to micron-sized filter pores (42). Currently, new lab-on-a-chip microfluidics devices have gradually appeared and significantly improved the GC- and CRC-CTCs yields compared with the conventional membrane microfiltration and EpCAM-based immunoaffinity assays $(43,44)$. Moreover, these technologies have provided improved in situ platforms for molecular analysis by fluorescent in situ hybridization (FISH) or immunofluorescence (IF) (45), as well as for the extraction of biomolecules for downstream genomic and transcriptomic sequencing (43). In addition, these platforms also provide the opportunity for CTCs release and ex vivo expansion, which lays an important foundation to further understand the biological characteristics of CTCs (46).

Previously, our group reported several biophysical propertybased assays of CTCs detection. We fabricated a label-free wedgeshaped microfluidic chip (named CTC- $\Delta$ chip) based on the size characteristics of CTCs, which exhibited high performance in capturing GC-CTCs and a great potential clinical value (24). Additionally, our group co-operated with YZY Medical Science and Technology Company (Wuhan, China) to develop a novel isolation by size of epithelial tumor cells device named CTCBIOPSY $^{\circledR}$ (Wuhan YZY Medical Science and Technology Co., Ltd., Wuhan, China), which achieved CTCs isolation and identification through a polymer membrane made by biocompatible parylene and Wright's staining (23). As a one-stop ISET device, CTCBIOPSY ${ }^{\circledR}$ exhibited excellent performance in capturing patients' CTCs and has now been approved by the China Food and Drug Administration (CFDA) for clinical application in cancer management $(23,26)$.

\section{Molecular (RNA-Based) Assays of CTCs (Without Prior Enrichment)}

The aforementioned immunoaffinity- or biophysical propertybased technologies of CTCs detection need to separate GCand CRC-CTCs from blood cells before identification. Molecular assays, represented by RT-PCR, can directly achieve the detection and characterization of CTCs by analyzing the expression of GC and CRC-CTCs-related genes without prior CTCs enrichment $(47,48)$. In contrast to enrichment technologies, RT-PCR has the advantages of being rapid, well-implemented, sensitive, and cost effective (41). Previously, our group conducted a series of metaanalyses to explore the clinical role of CTCs detected by RT-PCR in GC and CRC and summarized the commonly used markers for
GC-CTCs (including CK19, CK20, CEA, hTerT, c-MET, MUC1, VEGFR-1, Survivin, uPAR, B7-H3, and STCs) and CRC-CTCs (including CK19, CK20, CEA, PLS3, CD133, hTerT, EphB4, LAM $\gamma 2$, and MAT) detection $(25,49)$. Using these cancer-related genes for CTCs detection is of great value in evaluating the prognosis of patients with both GC and CRC $(25,49)$. However, tumor-derived circulating RNAs (such as miRNAs and lncRNAs) present in the blood of cancer patients may affect the accuracy of RT-PCR for CTCs detection, contributing a major limitation of this technology (41).

\section{Molecular Characterizing Technologies of CTCs}

After enrichment by the above platforms, the candidate CTCs need to be further identified as "true" CTCs. Currently, the identification and molecular characterization of CTCs is achieved by (a) immunocytochemistry (ICC)-based assays, including IF and immunohistochemistry (IHC), and (b) molecular approaches, including RT-qPCR, FISH and next-generation sequencing (NGS) (41). The most commonly used assay for the identification of GC- and CRC-CTCs from contaminating cells is IF, which achieves CTCs identification by staining and visualizing related-antibody biomarkers. Such biomarkers can be specific for nuclear content, epithelial proteins (i.e., CKs), mesenchymal proteins (i.e., vimentin), and hematopoietic markers (i.e., CD45). A common immunocytological CTC definition is nucleus+/CK+/vimentin-/CD45cell for epithelial-CTC, nucleus+/CK-/vimentin+/CD45- cell for mesenchymal-CTC, and nucleus+/CK+/vimentin+/CD45for epithelial/mesenchymal-CTC (50). However, the detection of CTCs by classical IF, which is typically performed by pathologists through the visual observation of stained CTCs based on the above principles, is time consuming and subjective-dependent. By contrast, PCR-based molecular assays provide objective and quantifiable CTCs measurements with the advantages of automated, sensitive, relatively low-cost and amenable to quantifiable quality control. Moreover, these methods require a small amount of cells for analysis, which is also in line with the fact that the amount of CTCs is less (51). However, since the molecular characterization of CTCs by PCR assays is based on the detection of mRNA markers that are specifically expressed in CTCs but not in leukocytes, the risk of false-positive results might be increased due to the non-specific amplification of RNA (50-52).

Notably, nucleic acid-based technologies, as improvements to non-fixating enrichment procedures, allow the use of RTPCR and qRT-PCR to amplify single or multiple gene transcripts for CTCs detection, and these technologies have provided an alternate avenue for the molecular characterization of GC- and CRC-CTCs (53-55). In particular, recent emerging single-cell sequencing techniques, including DNA and RNA sequencing, have turned the research direction toward analyzing the genetic characteristics of individual CTCs to assist in exploring tumor metastasis mechanisms, finding drug targets, monitoring therapy responses, and assessing drug resistance (54). Although, because single-cell CTC analyses are limited by the heterogeneity between 


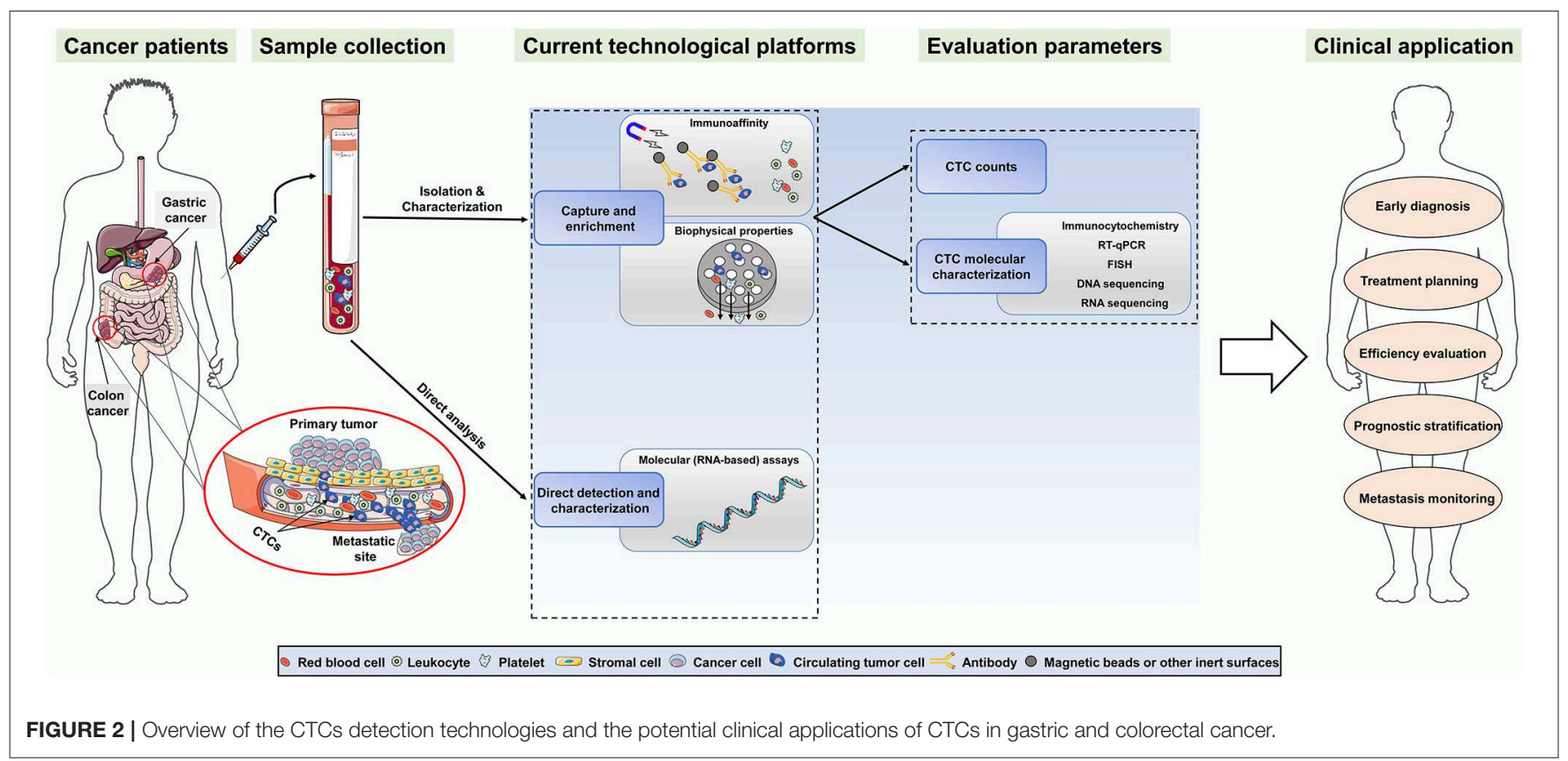

cancer subtypes, the usefulness of these analyses has hindered the discovery of universal markers (54).

\section{CLINICAL VALUE OF CTCS DETECTION IN GASTROINTESTINAL CANCER}

In recent years, the clinical applications of CTCs detection via various technologies have been gradually involved in multiple aspects of GI cancers, including early diagnosis, treatment planning, efficiency evaluation, prognostic stratification, and metastasis monitoring (56) (summarized in Figure 2). Despite this, there is still no universally applicable "gold standard" method so far $(41,56)$. Therefore, the aforementioned assays must be validated in clinical trials to achieve clinical validity and utility in the future.

\section{Prognostic Stratification}

The role of CTCs in the prognostic stratification of patients with GC and CRC, as the most studied aspect of CTCs' clinical value, has been demonstrated by numerous studies $(26,57-$ 91). For both GC and CRC, CTCs detection is considered to be significantly correlated with disease progression and patient's prognosis (56). Previously, our group conducted a prospective cohort study that recruited 138 patients with stage I-III CRC to assess the prognostic value of the change in CTCs counts before and after curative surgery. The results found that postoperative CTCs-positive but not preoperative CTCs-positive is an independent indicator of poor prognosis for CRC patients, and the patients with preoperative CTCspositive that normalized after surgery have similar outcomes to patients with preoperative CTC-negative (26). Meanwhile, our clinical study demonstrated that combining the preoperative controlling nutritional status score and circulating tumor cell status could strongly predict the prognosis for CRC patients treated with curative resection (92), which indicated that the state of CTCs in the blood is closely related to the nutrition and immune status of the host. In addition, a series of meta-analyses conducted by our group also provided strong evidence for the prognostic significance of CTCs detection in GI malignancies, which showed that CTCs-positive predicts a poor patient prognosis and unfavorable clinicopathological factors for both GC and CRC, regardless of whether the detection method was RT-PCR, CellSearch or cytological methods (25, $27,49,93)$. In these processes, an unneglectable fact is that CTCs detection at different time points during treatment might exhibit different prognostic significance (14). The reason is that a cancer (or a minimal residual disease) evolves with time, treatment, selection pressure from surgery, chemotherapy and radiotherapy and that tumoricidal immunity could stimulate the expansion of tumor subclones, leading to a change in the number and molecular characteristics of CTCs (94). In the future, repeated CTCs detection may be necessary to capture the changing genetics attributed to anticancer therapies. In the present review, we summarized the prognostic value of CTCs detection using different methods at different time points in GC and CRC (summarized in Table 1). As shown in Table 1, although there are many CTCs detection methods, none of them are generally accepted and could be really applied to clinical practice. At the same time, the cut-off values of the same CTCs detection method are different from study to study. Therefore, it is necessary for larger clinical studies to further validate whether CTCs are used in clinical practice to guide prognostic assessment. Of course, this may still have a long way to go.

\section{Therapeutic Implications}

Currently, there is limited evidence showing that CTCs detection at baseline can predict the response to systemic therapy in 
TABLE 1 | CTCs detection for prognosis of gastric and colorectal cancer.

\begin{tabular}{|c|c|c|c|c|c|c|c|c|}
\hline \multirow[t]{2}{*}{ Cancer types } & \multirow[t]{2}{*}{ Cut-off value } & \multirow[t]{2}{*}{ Technique } & \multirow[t]{2}{*}{ Patients $(n)$} & \multicolumn{2}{|c|}{ HR for death $(95 \% \mathrm{Cl})$} & \multicolumn{2}{|c|}{ HR for progression/recurrence $(95 \% \mathrm{Cl})$} & \multirow[t]{2}{*}{ References } \\
\hline & & & & Before treatment & After treatment & Before treatment & After treatment & \\
\hline \multirow[t]{12}{*}{ Gastric cancer } & $\geq 2.8 \mathrm{CTCs}$ & ISET & $\begin{array}{l}\text { Non-metastatic } \\
\text { GAC (88) }\end{array}$ & - & - & - & - & (57) \\
\hline & $\geq 5$ CTCs & CellSearch $^{\circledR}$ & $\begin{array}{l}\text { Resectable GC } \\
\text { (93) }\end{array}$ & - & - & - & - & (67) \\
\hline & >17 CTCs & IsoFlux ${ }^{\circledR}$ & $\begin{array}{l}\text { Stage II-IV EGC } \\
(43)\end{array}$ & $3.7(1.2-12.4)$ & - & - & - & (58) \\
\hline & $\geq 1$ CTCs & ISET & Stage II-IV GC (86) & $2.96(1.25-7.04)$ & - & $3.94(1.38-11.27)$ & - & (68) \\
\hline & $>2$ CTCs & CELLection $^{T M}$ & Stage II-IV GC (59) & $3.59(1.66-7.82)$ & $0.77(0.27-2.25)$ & $2.81(1.31-6.00)$ & $6.58(1.37-31.6)$ & (63) \\
\hline & $\geq 4$ CTCs & SE-iFISH & Advanced GC (31) & - & - & - & - & (62) \\
\hline & >5 CTCs & $\begin{array}{l}\text { GFP } \\
\text { fluorescence }\end{array}$ & Stage II-IV GC (65) & $0.90(0.29-2.59)$ & - & $1.97(0.47-8.86)$ & - & (59) \\
\hline & $\geq 3 \mathrm{cTCs}$ & CellSearch $^{\circledast}$ & $\begin{array}{l}\text { Advanced EGC } \\
\text { (106) }\end{array}$ & - & $3.46(1.82-6.58)$ & - & $2.15(1.11-4.16)$ & (61) \\
\hline & $\geq 2 \mathrm{CTCs}$ & Cytometry, FISH & $\begin{array}{l}\text { Advanced EGC } \\
(60)\end{array}$ & $4.30(0.82-22.90)$ & - & $6.70(1.43-31.03)$ & - & (64) \\
\hline & $\geq 1 \mathrm{CTCs}$ & CellSearch $^{\circledR}$ & $\begin{array}{l}\text { Advanced GC } \\
\text { (136) }\end{array}$ & $1.37(0.68-2.77)$ & - & $2.14(1.09-4.20)$ & - & (65) \\
\hline & $\geq 5$ CTCs & CellSearch ${ }^{\circledR}$ & $\begin{array}{l}\text { Advanced GC } \\
(100)\end{array}$ & $2.58(1.57-4.27)$ & - & 2.06 (1.26-3.38) & - & (60) \\
\hline & $\geq 1 \mathrm{CTCs}$ & CellSearch $^{\circledR}$ & $\begin{array}{l}\text { Resectable GC } \\
\text { (148) }\end{array}$ & $1.73(1.08-2.77)$ & - & - & - & (66) \\
\hline \multirow[t]{9}{*}{$\begin{array}{l}\text { Colorectal } \\
\text { cancer }\end{array}$} & $\geq 3$ CTCs & Cyttel+imFISH & $\begin{array}{l}\text { Advanced CRC } \\
\text { (121) }\end{array}$ & - & $2.68(1.19-6.03)$ & - & $2.79(1.01-7.71)$ & (69) \\
\hline & $\geq 4$ CTCs & CellSearch $^{\circledR}$ & $\begin{array}{l}\text { Non-metastatic } \\
\text { CRC (63) }\end{array}$ & $\begin{array}{c}41.03 \\
(0.00-102.40)\end{array}$ & - & $17.6(3.7-82.6)$ & - & (70) \\
\hline & $\geq 1 \mathrm{CTCs}$ & ISET & $\begin{array}{l}\text { Non-metastatic } \\
\text { CRC (138) }\end{array}$ & - & - & $2.17(0.75-6.31)$ & $2.82(1.39-5.75)$ & (26) \\
\hline & $\geq 1 \mathrm{CTCs}$ & $\begin{array}{l}\text { Immunomagnetic } \\
\text { selection }\end{array}$ & mCRC (77) & $0.32(0.72-2.79)$ & $0.35(0.12-0.99)$ & - & - & (71) \\
\hline & $\geq 1.92 \mathrm{CTCs}$ & $\begin{array}{l}\text { CEACAM5 } \\
\text { RT-PCR }\end{array}$ & mCRC (436) & $2.1(1.3-3.2)$ & - & $1.6(1.1-2.5)$ & - & (72) \\
\hline & $\geq 6$ CTCs & CanPatrol $^{\mathrm{TM}}$ & Stage I-IV (66) & $\begin{array}{c}59.7(0.002-1.6 \times \\
\left.10^{6}\right)\end{array}$ & - & $7.42(1.06-51.74)$ & - & (73) \\
\hline & $>30$ CTCs & Vita-Assay ${ }^{\mathrm{TM}}$ & Stage I-IV (88) & $1.04(1.01-1.06)$ & - & - & - & (74) \\
\hline & $\geq 2$ CTCs & CellSearch ${ }^{\circledR}$ & mCRC (79) & $2.51(0.69-9.09)$ & - & $3.28(1.24-8.67)$ & - & (75) \\
\hline & >30 CTCs & $\begin{array}{l}\text { Negative } \\
\text { selection }\end{array}$ & mCRC (55) & $2.61(1.39-4.93)$ & - & $4.94(2.60-9.39)$ & - & (76) \\
\hline
\end{tabular}


TABLE 1 | Continued

\begin{tabular}{|c|c|c|c|c|c|c|c|c|}
\hline \multirow[t]{2}{*}{ Cancer types } & \multirow[t]{2}{*}{ Cut-off value } & \multirow[t]{2}{*}{ Technique } & \multirow[t]{2}{*}{ Patients (n) } & \multicolumn{2}{|c|}{ HR for death $(95 \% \mathrm{Cl})$} & \multicolumn{2}{|c|}{ HR for progression/recurrence $(95 \% \mathrm{Cl})$} & \multirow[t]{2}{*}{ References } \\
\hline & & & & Before treatment & After treatment & Before treatment & After treatment & \\
\hline & NR & $\begin{array}{l}\text { Multiparameter } \\
\text { flow cytometry }\end{array}$ & mCRC (152) & $6.46(1.46-28.56)$ & - & - & - & (77) \\
\hline & $\geq 1 \mathrm{CTCs}$ & ISET & Stage II-IV (98) & - & $1.15(0.68-1.94)$ & - & $1.99(1.14-3.48)$ & (78) \\
\hline & $\begin{array}{l}\geq 1+P C R \text { test } \\
\text { out of } 3\end{array}$ & CK20 RT-PCR & $\begin{array}{l}\text { Resectable colon } \\
\text { cancer (299) }\end{array}$ & $1.94(1.0-3.7)$ & - & $1.94(1.1-3.7)$ & - & (79) \\
\hline & $\geq 1 \mathrm{CTC}$ & CellSearch $^{\circledR}$ & $\begin{array}{l}\text { Stage I-III CRC } \\
\text { (239) }\end{array}$ & $5.5(2.3-13.6)$ & - & $12.7(5.2-31.1)$ & - & (80) \\
\hline & & & $\begin{array}{l}\text { Stage I-IV CRC } \\
\text { (287) }\end{array}$ & $5.6(2.6-12.0)$ & - & $7.8(3.9-15.5)$ & - & \\
\hline & $\geq 1 \mathrm{CTC}$ & CellSearch $^{\circledR}$ & $\begin{array}{l}\text { Stage III CRC } \\
(519)\end{array}$ & - & $0.96(0.56-1.65)$ & - & $0.97(0.65-1.45)$ & (81) \\
\hline & $\geq 2$ CTCs & CellSearch $^{\circledR}$ & $\begin{array}{l}\text { Resectable CRC } \\
\text { LM (194) }\end{array}$ & $2.48(1.40-4.38)$ & - & $2.32(1.26-4.27)$ & - & (82) \\
\hline & $\begin{array}{l}>0.1 \mathrm{ng} / \mu \mathrm{L} \text { for } \\
\geq 1 \text { out of } 3 \text { gene }\end{array}$ & AdnaTest ${ }^{\circledR}$ & $\begin{array}{l}\text { Metastatic } \\
\text { RAS-BRAF wt } \\
\text { CRC (38) }\end{array}$ & $9.32(2.63-33.1)$ & - & $6.24(2.54-15.3)$ & - & (83) \\
\hline & $\geq 1 \mathrm{CTC}$ & CellSearch $^{\circledR}$ & $\begin{array}{l}\text { Resectable colon } \\
\text { cancer (183) }\end{array}$ & $2.88(1.46-5.66)$ & - & $1.96(1.06-3.61)$ & - & (84) \\
\hline & $\geq 3$ CTCs & CellSearch $^{\circledR}$ & $\begin{array}{l}\text { Metastatic KRAS } \\
\text { wt CRC (63) }\end{array}$ & $2.08(1.16-3.73)$ & - & - & - & (85) \\
\hline & $\geq 1 \mathrm{CTC}$ & CellSearch $^{\circledR}$ & mCRC (119) & - & - & $2.05(1.29-3.28)$ & - & (86) \\
\hline & $\geq 3$ CTCs & CellSearch $^{\circledR}$ & mCRC (180) & $1.54(1.00-2.37)$ & - & $1.47(0.98-2.22)$ & - & (87) \\
\hline & $\geq 3 \mathrm{CTCs}$ & CellSearch $^{\circledR}$ & mCRC (64) & - & $1.44(1.14-1.82)$ & $1.06(0.98-1.15)$ & $1.21(1.09-1.34)$ & (88) \\
\hline & $\begin{array}{l}\text { All markers } \\
\text { positive }\end{array}$ & $\begin{array}{l}\text { CK19, CK20, } \\
\text { CEA, CD133 } \\
\text { RT-PCR }\end{array}$ & $\begin{array}{l}\text { Resectable CRC } \\
\text { (315) }\end{array}$ & $3.20(1.67-6.31)$ & - & 3.04 (1.79-5.22) & - & (89) \\
\hline & $\geq 3$ CTCs & CellSearch $^{\circledR}$ & mCRC (467) & 1.9 & - & 1.4 & - & (90) \\
\hline & $>3$ CTCs & CellSearch ${ }^{\circledR}$ & mCRC (430) & $2.45(1.77-3.39)$ & $9.35(5.28-16.54)$ & $1.74(1.33-2.26)$ & $3.64(2.10-6.30)$ & (91) \\
\hline
\end{tabular}

CTCS, circulating tumor cells; HR, hazard ratio; Cl, confidence interval; ISET, isolation by size of epithelial tumor cells; GAC, gastric adenocarcinoma; GC, gastric cancer: EGC, esophagogastric cancer; FISH, fluorescent in situ hybridization; $C R C$, colorectal cancer; $M C R C$, metastatic CRC; RT-PCR, real-time polymerase chain reaction; CK, cytokine; CEA, carcinoembryonic antigen; wt: wild type; LM, lung metastasis; NR, not reported. 
TABLE 2 | CTCs as predictive factors for cancer therapy efficacy in gastric and colorectal cancer

\begin{tabular}{|c|c|c|c|c|c|c|}
\hline Cancer types & Cut-off value & Technique & Patients $(n)$ & Treatment & Conclusions & References \\
\hline \multirow[t]{4}{*}{ Gastric cancer } & $\geq 1 \mathrm{CTC}$ & 3D-IF-FISH method & $\begin{array}{l}\text { Unresectable } \\
\text { metastatic or recurrent } \\
\text { GC (15) }\end{array}$ & $\begin{array}{l}\text { 1st-line } \mathrm{CT}+ \\
\text { trastuzumab }\end{array}$ & $\begin{array}{l}\text { ORR was } 53.3 \% \text { in CTCs-HER2 positive patients at } \\
\text { first response evaluation ( } 6 \text { weeks) vs. } 7.7 \% \text { in } \\
\text { CTCs-HER2 negative patients ( } p=0.016 \text { ) }\end{array}$ & (98) \\
\hline & $\geq 3 \mathrm{CTCs}$ & CellSearch $^{\circledR}$ & Advanced GC (106) & 1st-line CT & $\begin{array}{l}\text { ORR was } 30.0 \% \text { in CTCs-negative patients at first } \\
\text { response evaluation }\end{array}$ & (61) \\
\hline & $\geq 5$ CTCs & CellSearch ${ }^{\circledR}$ & Metastatic GC (100) & $\geq 1$ st-line CT & $\begin{array}{l}\text { Chemotherapy response (CR or PR or SD) was } \\
76.6 \% \text { in CTCs-negative patients vs. } 40.0 \% \text { in } \\
\text { CTCs-positive patients ( } p=0.004 \text { ) }\end{array}$ & (60) \\
\hline & $\begin{array}{l}\geq 1 \text { of the marker } \\
\text { genes positive }\end{array}$ & EpCAM + RT-PCR & Advanced GC (61) & 1st or 2nd-line CT & $\begin{array}{l}100 \% \text { of progressive patients were CTCs-positive at } \\
\text { baseline vs. } 73.5 \% \text { of non-progressive patients } \\
(p=0.003)\end{array}$ & (96) \\
\hline \multirow[t]{8}{*}{$\begin{array}{l}\text { Colorectal } \\
\text { cancer }\end{array}$} & $2+$ PCR results & RT-PCR & LARC (79) & CRT + surgery & $\begin{array}{l}\text { After CRT, CTCs were detected in } 54.4 \% \text { of the } \\
\text { non-responders vs. } 27.2 \% \text { of the responders } \\
(p=0.030)\end{array}$ & (95) \\
\hline & $\geq 1 \mathrm{CTC}$ & CellSearch $^{\circledR}$ & LARC (85) & CRT + surgery & $\begin{array}{l}\mathrm{pCR} / \text { downstaging/downsizing rate was } 80 \% \text { in } \\
\text { baseline CTCs-negative patients vs. } 40 \% \text { in } \\
\text { CTCs-positive patients ( } p=0.02 \text { ) }\end{array}$ & (97) \\
\hline & $\begin{array}{l}\geq 1 \text { out of } 3 \\
\text { CTCs markers }\end{array}$ & AdnaTest ${ }^{\circledR}$ & $\begin{array}{l}\text { Metastatic RAS-BRAF } \\
\text { wt CRC (38) }\end{array}$ & $\geq 1$ st-line CT & $\begin{array}{l}\text { ORR in unfavorable and favorable CTCs-changes } \\
\text { profiles were respectively } 0 \% \text { and } 59 \%(p<0.0001)\end{array}$ & (83) \\
\hline & $\geq 3$ CTCs & CellSearch $^{\circledR}$ & $\begin{array}{l}\text { Metastatic KRAS wt } \\
\text { CRC (61) }\end{array}$ & 3rd-line CT & $\begin{array}{l}\text { ORR was not different between the high and the low } \\
\text { CTCs groups ( } 27.7 \text { vs. } 18.36 \%, p=0.498 \text { ) }\end{array}$ & (85) \\
\hline & $\geq 3$ CTCs & CellSearch $^{\circledR}$ & mCRC (180) & 1st-line CT & $\begin{array}{l}\text { CTCs negativity after } 3 \text { cycles of CT was associated } \\
\text { with higher ORR (OR, 3.22; } 95 \% \text { Cl 1.25-9.43) }\end{array}$ & (87) \\
\hline & $\geq 3 \mathrm{CTCs}$ & CellSearch $^{\circledR}$ & mCRC (60) & 1st or 2nd-line CT & $\begin{array}{l}\text { CTCs positivity at } 8-12 \text { weeks was } 2 \% \text { in non-PD } \\
\text { patients vs. } 43 \% \text { in PD patients }(p=0.004)\end{array}$ & (88) \\
\hline & $\geq 3$ CTCs & CellSearch $^{\circledR}$ & mCRC (307) & 1st-line CT & $\begin{array}{l}\text { ORR was } 40 \% \text { in patients with low CTCs count at } \\
1-2 \text { weeks vs. } 11 \% \text { in patients with high CTCs } \\
\text { count }(p=0.022)\end{array}$ & (90) \\
\hline & $\geq 3 \mathrm{CTCs}$ & CellSearch $^{\circledR}$ & mCRC (430) & 1st, 2nd, or 3rd CT & $\begin{array}{l}\text { CTCs positivity at } 3-5 \text { weeks was } 7 \% \text { in non-PD } \\
\text { patients vs. } 27 \% \text { in PD patients }\end{array}$ & (91) \\
\hline
\end{tabular}

CTCs, circulating tumor cells; GC, gastric cancer; CRC, colorectal cancer; mCRC, metastatic CRC; LARC, localize advanced rectum cancer; IF, immunofluorescence; FISH, fluorescent in situ hybridization; EpCAM, epithelial marker epithelial cell adhesion molecule; HER2, human epidermal growth factor receptor 2; RT-PCR, real-time polymerase chain reaction; CT, chemotherapy; CRT, chemoradiotherapy; CR, complete response; PR, part response; SD, stable disease; $O R R$, overall response rate $=$ complete response + partial response; $O R$, odds ratio. 
GI cancers $(60,61,83,85,87,88,90,91,95-98)$. However, a few studies have demonstrated the predictive value of CTCs detection during chemotherapy (summarized in Table 2). Li et al. conducted a single-center, prospective study to measure the level of CTCs before and at 6 weeks of chemotherapy in 136 patients with newly diagnosed advanced GC, and the results showed that the posttherapy CTCs levels may help evaluate the therapeutic response; in addition, the changes in CTCs following therapy may be useful in rapidly identifying ineffective treatments for patients with advanced GC (61). Similarly, a study including 430 patients with metastatic CRC also found that there were significantly higher disease progression rates among patients who were CTCs-positive after 3-4 weeks of chemotherapy (91). Additionally, CTCs have also been used as a vehicle to assess genotyping changes in primary tumor and metastatic lesions; this is relevant for patients for whom a targeted therapy against known resistance-causing mutations is available, such as HER2-directed treatment for GC and EGFR-directed treatment for CRC (14). Overall, although the therapeutic predictive value of CTCs is not as well-studied as their prognostic value, using CTCs detection for determining the choice of systemic treatment and monitoring the treatment effects is promising, illustrating the possibility of liquid biopsy assessments to change future cancer management.

\section{Early Diagnosis}

In the early stage of the disease, tumor cells may separate from the primary tumor and enter the bloodstream; this circumstance provides a theoretical basis for CTCs detection as a tool for early diagnosis. Over the past few years, several studies have explored the early diagnostic value of CTCs detection based on different methods in GI malignancies, and the results found that the fraction of patients positive for CTCs is generally considered too low to obtain sufficient sensitivities for true early diagnosis $(66,99-101)$. Therefore, screening general populations with a CTCs assessment is not logistically realistic, but may be realistic in the high-risk groups, such as those with a family history of GI cancers.

\section{REFERENCES}

1. Bray F, Ferlay J, Soerjomataram I, Siegel RL, Torre LA, Jemal A. Global cancer statistics 2018: GLOBOCAN estimates of incidence and mortality worldwide for 36 cancers in 185 countries. CA Cancer J Clin. (2018) 68:394-424. doi: $10.3322 /$ caac. 21492

2. Abreu MT, Peek RM Jr. Gastrointestinal malignancy and the microbiome. Gastroenterology. (2014) 146:1534-46.e3. doi: 10.1053/j.gastro.2014.01.001

3. Pantel K, Brakenhoff RH. Dissecting the metastatic cascade. Nat Rev Cancer. (2004) 4:448-56. doi: 10.1038/nrc1370

4. Miller KD, Siegel RL, Lin CC, Mariotto AB, Kramer JL, Rowland JH, et al. Cancer treatment and survivorship statistics, 2016. CA Cancer J Clin. (2016) 66:271-89. doi: 10.3322/caac.21349

5. Klein CA. Parallel progression of primary tumours and metastases. Nat Rev Cancer. (2009) 9:302-12. doi: 10.1038/nrc2627

\section{CONCLUDING REMARKS}

Although the detection and measurement of CTCs is expected to become a promising tool as prognostic, predictive, and diagnostic markers for patients with GC and CRC, CTCs have yet to be realized owing to residual surmountable challenges. To achieve this goal, a CTCs detection device that is universally accepted, fast, and low-cost with low false-negative and false-positive results is first needed; simultaneously, standard procedures for CTCs detection must also be established. Then, clinical research into CTCs as a circulating marker needs to be performed, and issues and promising results should be validated in large-scale, long-term follow-up, prospective clinical trials to ensure clinical applicability. Furthermore, conducting more basic research to gain an in-depth understanding of cancer biology may provide new insights into how and when to perform CTCs detection with the best clinical use. Despite these obstacles, we still have enough reason to believe that, with advances in detection and subsequent analytical techniques, CTCs will provide abundant useful information for the diagnosis and therapy in clinical practice for patients with GI cancers in the near future.

\section{AUTHOR CONTRIBUTIONS}

BX designed the review. CY and FC drafted the manuscript and prepared the figures. SW helped to modify the manuscript. All authors read and approved the final manuscript.

\section{FUNDING}

This work was supported by the Science Fund of the National Natural Science Foundation of China (Nos. 81572874; 81702411) and Health Commission of Hubei Province Scientific Research Project (No. WJ2019H012).

\section{ACKNOWLEDGMENTS}

The authors would like to thank Wuhan YZY Medical Science and Technology Co., Ltd. for providing equipment and excellent technical support for our CTCs study.

6. Micalizzi DS, Maheswaran S, Haber DA. A conduit to metastasis: circulating tumor cell biology. Genes Dev. (2017) 31:1827-40. doi: $10.1101 / \operatorname{gad} .305805 .117$

7. Massague J, Obenauf AC. Metastatic colonization by circulating tumour cells. Nature. (2016) 529:298-306. doi: 10.1038/nature17038

8. Williams SC. Circulating tumor cells. Proc Natl Acad Sci USA. (2013) 110:4861. doi: 10.1073/pnas.1304186110

9. Shen Z, Wu A, Chen X. Current detection technologies for circulating tumor cells. Chem Soc Rev. (2017) 46:2038-56. doi: 10.1039/C6CS00803H

10. Pantel K, Alix-Panabieres C. Circulating tumour cells in cancer patients: challenges and perspectives. Trends Mol Med. (2010) 16:398-406. doi: 10.1016/j.molmed.2010.07.001

11. Jackson JM, Witek MA, Kamande JW, Soper SA. Materials and microfluidics: enabling the efficient isolation and analysis of circulating tumour cells. Chem Soc Rev. (2017) 46:4245-80. doi: 10.1039/C7CS00016B 
12. Esmaeilsabzali H, Beischlag TV, Cox ME, Parameswaran AM, Park EJ. Detection and isolation of circulating tumor cells: principles and methods. Biotechnol Adv. (2013) 31:1063-84. doi: 10.1016/j.biotechadv.2013.08.016

13. Myung JH, Park SJ, Wang AZ, Hong S. Integration of biomimicry and nanotechnology for significantly improved detection of circulating tumor cells (CTCs). Adv Drug Deliv Rev. (2018) 125:36-47. doi: 10.1016/j.addr.2017.12.005

14. Moon DH, Lindsay DP, Hong S, Wang AZ. Clinical indications for, and the future of, circulating tumor cells. Adv Drug Deliv Rev. (2018) 125:143-50. doi: 10.1016/j.addr.2018.04.002

15. Zhang N, Deng Y, Tai Q, Cheng B, Zhao L, Shen Q, et al. Electrospun $\mathrm{TiO} 2$ nanofiber-based cell capture assay for detecting circulating tumor cells from colorectal and gastric cancer patients. Adv Mater. (2012) 24:2756-60. doi: 10.1002/adma.201200155

16. Shen Q, Xu L, Zhao L, Wu D, Fan Y, Zhou Y, et al. Specific capture and release of circulating tumor cells using aptamer-modified nanosubstrates. Adv Mater. (2013) 25:2368-73. doi: 10.1002/adma.201300082

17. He R, Zhao L, Liu Y, Zhang N, Cheng B, He Z, et al. Biocompatible TiO2 nanoparticle-based cell immunoassay for circulating tumor cells capture and identification from cancer patients. Biomed Microdevices. (2013) 15:617-26. doi: 10.1007/s10544-013-9781-9

18. Cheng B, He Z, Zhao L, Fang Y, Chen Y, He R, et al. Transparent, biocompatible nanostructured surfaces for cancer cell capture and culture. Int J Nanomed. (2014) 9:2569-80. doi: 10.2147/IJN.S61233

19. Cheng B, Song H, Wang S, Zhang C, Wu B, Chen Y, et al. Quantification of rare cancer cells in patients with gastrointestinal cancer by nanostructured substrate. Transl Oncol. (2014) 7:720-5. doi: 10.1016/j.tranon.2014.10.001

20. Chen YY, Cheng BR, He ZB, Wang SY, Wang ZM, Sun M, et al. Capture and identification of heterogeneous circulating tumor cells using transparent nanomaterials and quantum dots-based multiplexed imaging. J Cancer. (2016) 7:69-79. doi: 10.7150/jca.12722

21. Cheng B, Wang S, Chen Y, Fang Y, Chen F, Wang Z, et al. A combined negative and positive enrichment assay for cancer cells isolation and purification. Technol Cancer Res Treat. (2016) 15:69-76. doi: $10.7785 /$ tcrt.2012.500447

22. Wang S, Zhang C, Wang G, Cheng B, Wang Y, Chen F, et al. Aptamer-mediated transparent-biocompatible nanostructured surfaces for hepotocellular circulating tumor cells enrichment. Theranostics. (2016) 6:1877-86. doi: 10.7150/thno.15284

23. Chen F, Wang S, Fang Y, Zheng L, Zhi X, Cheng B, et al. Feasibility of a novel one-stop ISET device to capture CTCs and its clinical application. Oncotarget. (2017) 8:3029-41. doi: 10.18632/oncotarget.13823

24. Yang C, Zhang N, Wang S, Shi D, Zhang C, Liu K, et al. Wedgeshaped microfluidic chip for circulating tumor cells isolation and its clinical significance in gastric cancer. J Transl Med. (2018) 16:139. doi: 10.1186/s12967-018-1521-8

25. Yang C, Zou K, Zheng L, Xiong B. Prognostic and clinicopathological significance of circulating tumor cells detected by RT-PCR in non-metastatic colorectal cancer: a meta-analysis and systematic review. BMC Cancer. (2017) 17:725. doi: 10.1186/s12885-017-3704-8

26. Yang C, Shi D, Wang S, Wei C, Zhang C, Xiong B. Prognostic value of pre- and post-operative circulating tumor cells detection in colorectal cancer patients treated with curative resection: a prospective cohort study based on ISET device. Cancer Manag Res. (2018) 10:4135-44. doi: 10.2147/CMAR.S176575

27. Yang C, Zou K, Yuan Z, Guo T, Xiong B. Prognostic value of circulating tumor cells detected with the CellSearch System in patients with gastric cancer: evidence from a meta-analysis. Onco Targets Ther. (2018) 11:101323. doi: 10.2147/OTT.S154114

28. Shahneh FZ. Sensitive antibody-based CTCs detection from peripheral blood. Hum Antibodies. (2013) 22:51-4. doi: 10.3233/HAB-130270

29. Pastuszak M, Groszewski K, Pastuszak M, Dyrla P, Wojtun S, Gil J. Cytokeratins in gastroenterology. Systematic review. Prz Gastroenterol. (2015) 10:61-70. doi: 10.5114/pg.2015.51182

30. Chaudry MA, Sales K, Ruf P, Lindhofer H, Winslet MC. EpCAM an immunotherapeutic target for gastrointestinal malignancy: current experience and future challenges. Br J Cancer. (2007) 96:1013-9. doi: $10.1038 /$ sj.bjc. 6603505
31. Kujawski R, Mik M, Przybylowska-Sygut K, Majsterek I, Dziki A. Circulating tumor cells in colorectal cancer. Pol Przegl Chir. (2015) 87:277-81. doi: 10.1515/pjs-2015-0054

32. Galletti G, Sung MS, Vahdat LT, Shah MA, Santana SM, Altavilla G, et al. Isolation of breast cancer and gastric cancer circulating tumor cells by use of an anti HER2-based microfluidic device. Lab Chip. (2014) 14:147-56. doi: 10.1039/C3LC51039E

33. Gorges TM, Stein A, Quidde J, Hauch S, Rock K, Riethdorf S, et al. Improved detection of circulating tumor cells in metastatic colorectal cancer by the combination of the CellSearch(R) system and the adnatest(R). PLoS ONE. (2016) 11:e0155126. doi: 10.1371/journal.pone.0155126

34. Lin HC, Hsu HC, Hsieh CH, Wang HM, Huang CY, Wu MH, et al. A negative selection system PowerMag for effective leukocyte depletion and enhanced detection of EpCAM positive and negative circulating tumor cells. Clin Chim Acta. (2013) 419:77-84. doi: 10.1016/j.cca.2013.01.018

35. Wong LS, Bateman WJ, Morris AG, Fraser IA. Detection of circulating tumour cells with the magnetic activated cell sorter. Br J Surg. (1995) 82:1333-7. doi: 10.1002/bjs.1800821012

36. Nagrath S, Sequist LV, Maheswaran S, Bell DW, Irimia D, Ulkus L, et al. Isolation of rare circulating tumour cells in cancer patients by microchip technology. Nature. (2007) 450:1235-9. doi: 10.1038/nature06385

37. Xia J, Chen X, Zhou CZ, Li YG, Peng ZH. Development of a lowcost magnetic microfluidic chip for circulating tumour cell capture. IET Nanobiotechnol. (2011) 5:114-20. doi: 10.1049/iet-nbt.2011.0024

38. Andree KC, van Dalum G, Terstappen LW. Challenges in circulating tumor cell detection by the CellSearch system. Mol Oncol. (2016) 10:395-407. doi: 10.1016/j.molonc.2015.12.002

39. Murlidhar V, Rivera-Baez L, Nagrath S. Affinity versus label-free isolation of circulating tumor cells: who wins? Small. (2016) 12:4450-63. doi: 10.1002/smll.201601394

40. Jin C, McFaul SM, Duffy SP, Deng X, Tavassoli P, Black PC, et al. Technologies for label-free separation of circulating tumor cells: from historical foundations to recent developments. Lab Chip. (2014) 14:32-44. doi: 10.1039/C3LC50625H

41. Nordgard O, Tjensvoll K, Gilje B, Soreide K. Circulating tumour cells and DNA as liquid biopsies in gastrointestinal cancer. Br J Surg. (2018) 105:e11020. doi: 10.1002/bjs.10782

42. Hao SJ, Wan Y, Xia YQ, Zou X, Zheng SY. Size-based separation methods of circulating tumor cells. Adv Drug Deliv Rev. (2018) 125:3-20. doi: 10.1016/j.addr.2018.01.002

43. Khamenehfar A, Li PC. Microfluidic devices for circulating tumor cells isolation and subsequent analysis. Curr Pharm Biotechnol. (2016) 17:810-21. doi: 10.2174/1389201017666160301103509

44. Shields CWt, Reyes CD, Lopez GP. Microfluidic cell sorting: a review of the advances in the separation of cells from debulking to rare cell isolation. Lab Chip. (2015) 15:1230-49. doi: 10.1039/C4LC01246A

45. Xu Y, Qin T, Li J, Wang X, Gao C, Xu C, et al. Detection of circulating tumor cells using negative enrichment immunofluorescence and an in situ hybridization system in pancreatic cancer. Int J Mol Sci. (2017) 18:E622. doi: 10.3390/ijms18040622

46. Chen JY, Tsai WS, Shao HJ, Wu JC, Lai JM, Lu SH, et al. Sensitive and specific biomimetic lipid coated microfluidics to isolate viable circulating tumor cells and microemboli for cancer detection. PLoS ONE. (2016) 11:e0149633. doi: 10.1371/journal.pone.0149633

47. Valladares-Ayerbes M, Diaz-Prado S, Reboredo M, Medina V, IglesiasDiaz P, Lorenzo-Patino MJ, et al. Bioinformatics approach to mRNA markers discovery for detection of circulating tumor cells in patients with gastrointestinal cancer. Cancer Detect Prev. (2008) 32:236-50. doi: 10.1016/j.cdp.2008.08.002

48. Valladares-Ayerbes M, Diaz-Prado S, Reboredo M, Medina V, LorenzoPatino MJ, Iglesias-Diaz P, et al. Evaluation of plakophilin-3 mRNA as a biomarker for detection of circulating tumor cells in gastrointestinal cancer patients. Cancer Epidemiol Biomarkers Prev. (2010) 19:1432-40. doi: 10.1158/1055-9965.EPI-10-0123

49. Wang S, Zheng G, Cheng B, Chen F, Wang Z, Chen Y, et al. Circulating tumor cells (CTCs) detected by RT-PCR and its prognostic role in gastric cancer: a meta-analysis of published literature. PLOS ONE. (2014) 9:e99259. doi: 10.1371/journal.pone.0099259 
50. Mansilla C, Soria E, Ramirez N. The identification and isolation of CTCs: a biological Rubik's cube. Crit Rev Oncol Hematol. (2018) 126:129-34. doi: 10.1016/j.critrevonc.2018.03.027

51. Rawal S, Yang YP, Cote R, Agarwal A. Identification and quantitation of circulating tumor cells. Annu Rev Anal Chem. (2017) 10:321-43. doi: 10.1146/annurev-anchem-061516-045405

52. Lampignano R, Schneck H, Neumann M, Fehm T, Neubauer H. Enrichment, isolation and molecular characterization of EpCAMnegative circulating tumor cells. Adv Exp Med Biol. (2017) 994:181-203. doi: 10.1007/978-3-319-55947-6_10

53. Song Y, Tian T, Shi Y, Liu W, Zou Y, Khajvand T, et al. Enrichment and single-cell analysis of circulating tumor cells. Chem Sci. (2017) 8:1736-51. doi: 10.1039/C6SC04671A

54. Zhu Z, Qiu S, Shao K, Hou Y. Progress and challenges of sequencing and analyzing circulating tumor cells. Cell Biol Toxicol. (2018) 34:405-15. doi: 10.1007/s10565-017-9418-5

55. Ramskold D, Luo S, Wang YC, Li R, Deng Q, Faridani OR, et al. Full-length mRNA-Seq from single-cell levels of RNA and individual circulating tumor cells. Nat Biotechnol. (2012) 30:777-82. doi: 10.1038/nbt.2282

56. Pantel K, Alix-Panabieres C. Liquid biopsy in 2016: circulating tumour cells and cell-free DNA in gastrointestinal cancer. Nat Rev Gastroenterol Hepatol. (2017) 14:73-4. doi: 10.1038/nrgastro.2016.198

57. Abdallah EA, Braun AC, Flores B, Senda L, Urvanegia AC, Calsavara V, et al. The potential clinical implications of circulating tumor cells and circulating tumor microemboli in gastric cancer. Oncologist. (2019) 24:e85463. doi: 10.1634/theoncologist.2018-0741

58. Brungs D, Lynch D, Luk AW, Minaei E, Ranson M, Aghmesheh M, et al. Cryopreservation for delayed circulating tumor cell isolation is a valid strategy for prognostic association of circulating tumor cells in gastroesophageal cancer. World J Gastroenterol. (2018) 24:810-8. doi: 10.3748/wjg.v24.i7.810

59. Ito H, Sato J, Tsujino Y, Yamaguchi N, Kimura S, Gohda K, et al. Longterm prognostic impact of circulating tumour cells in gastric cancer patients. World J Gastroenterol. (2016) 22:10232-41. doi: 10.3748/wjg.v22.i46. 10232

60. Lee SJ, Lee J, Kim ST, Park SH, Park JO, Park YS, et al. Circulating tumor cells are predictive of poor response to chemotherapy in metastatic gastric cancer. Int J Biol Markers. (2015) 30:e382-6. doi: 10.5301/jbm.50 00151

61. Li Y, Gong J, Zhang Q, Lu Z, Gao J, Li Y, et al. Dynamic monitoring of circulating tumour cells to evaluate therapeutic efficacy in advanced gastric cancer. Br J Cancer. (2016) 114:138-45. doi: 10.1038/bjc.2015.417

62. Li Y, Zhang X, Gong J, Zhang Q, Gao J, Cao Y, et al. Aneuploidy of chromosome 8 in circulating tumor cells correlates with prognosis in patients with advanced gastric cancer. Chin J Cancer Res. (2016) 28:579-88. doi: 10.21147/j.issn.1000-9604.2016.06.04

63. Liu Y, Ling Y, Qi Q, Lan F, Zhu M, Zhang Y, et al. Prognostic value of circulating tumor cells in advanced gastric cancer patients receiving chemotherapy. Mol Clin Oncol. (2017) 6:235-42. doi: $10.3892 / \mathrm{mco} .2017 .1125$

64. Meulendijks D, de Groot JW, Los M, Boers JE, Beerepoot LV, Polee $\mathrm{MB}$, et al. Bevacizumab combined with docetaxel, oxaliplatin, and capecitabine, followed by maintenance with capecitabine and bevacizumab, as first-line treatment of patients with advanced HER2-negative gastric cancer: a multicenter phase 2 study. Cancer. (2016) 122:1434-43. doi: $10.1002 /$ cncr.29864

65. Okabe H, Tsunoda S, Hosogi H, Hisamori S, Tanaka E, Tanaka $\mathrm{S}$, et al. Circulating tumor cells as an independent predictor of survival in advanced gastric cancer. Ann Surg Oncol. (2015) 22:3954-61. doi: 10.1245/s10434-015-4483-6

66. Uenosono Y, Arigami T, Kozono T, Yanagita S, Hagihara T, Haraguchi $\mathrm{N}$, et al. Clinical significance of circulating tumor cells in peripheral blood from patients with gastric cancer. Cancer. (2013) 119:3984-91. doi: $10.1002 /$ cncr.28309

67. Zhang Q, Shan F, Li Z, Gao J, Li Y, Shen L, et al. A prospective study on the changes and clinical significance of pre-operative and post-operative circulating tumor cells in resectable gastric cancer. J Transl Med. (2018) 16:171. doi: 10.1186/s12967-018-1544-1
68. Zheng X, Fan L, Zhou P, Ma H, Huang S, Yu D, et al. Detection of circulating tumor cells and circulating tumor microemboli in gastric cancer. Transl Oncol. (2017) 10:431-41. doi: 10.1016/j.tranon.2017.02.007

69. Wang L, Zhou S, Zhang W, Wang J, Wang M, Hu X, et al. Circulating tumor cells as an independent prognostic factor in advanced colorectal cancer: a retrospective study in 121 patients. Int J Colorectal Dis. (2019) 34:589-97. doi: 10.1007/s00384-018-03223-9

70. Bahnassy AA, Salem SE, Mohanad M, Abulezz NZ, Abdellateif MS, Hussein $\mathrm{M}$, et al. Prognostic significance of circulating tumor cells (CTCs) in Egyptian non-metastatic colorectal cancer patients: a comparative study for four different techniques of detection (Flowcytometry, CellSearch, Quantitative Real-time PCR and Cytomorphology). Exp Mol Pathol. (2019) 106:90-101. doi: 10.1016/j.yexmp.2018.12.006

71. Delgado-Urena M, Ortega FG, de Miguel-Perez D, Rodriguez-Martinez A, Garcia-Puche JL, Ilyine $\mathrm{H}$, et al. Circulating tumor cells criteria (CyCAR) versus standard RECIST criteria for treatment response assessment in metastatic colorectal cancer patients. J Transl Med. (2018) 16:251. doi: 10.1186/s12967-018-1624-2

72. Messaritakis I, Sfakianaki M, Papadaki C, Koulouridi A, Vardakis N, Koinis F, et al. Prognostic significance of CEACAM5mRNA-positive circulating tumor cells in patients with metastatic colorectal cancer. Cancer Chemother Pharmacol. (2018) 82:767-75. doi: 10.1007/s00280-018-3666-9

73. Wang W, Wan L, Wu S, Yang J, Zhou Y, Liu F, et al. Mesenchymal marker and LGR5 expression levels in circulating tumor cells correlate with colorectal cancer prognosis. Cell Oncol. (2018) 41:495-504. doi: 10.1007/s13402-018-0386-4

74. Zhang Y, Zarrabi K, Hou W, Madajewicz S, Choi M, Zucker S, et al. Assessing clinical outcomes in colorectal cancer with assays for invasive circulating tumor cells. Biomedicines. (2018) 6:E69. doi: 10.3390/biomedicines6020069

75. Hashimoto M, Tanaka F, Yoneda K, Takuwa T, Kuroda A, Matsumoto S, et al. The clinical value of circulating tumour cells (CTCs) in patients undergoing pulmonary metastasectomy for metastatic colorectal cancer. J Thorac Dis. (2018) 10:1569-77. doi: 10.21037/jtd.2018.03.05

76. Chou WC, Wu MH, Chang PH, Hsu HC, Chang GJ, Huang WK, et al. A prognostic model based on circulating tumour cells is useful for identifying the poorest survival outcome in patients with metastatic colorectal cancer. Int J Biol Sci. (2018) 14:137-46. doi: 10.7150/ijbs.23182

77. Fang C, Fan C, Wang C, Huang Q, Meng W, Yu Y, et al. Prognostic value of CD133(+) CD54(+) CD44(+) circulating tumor cells in colorectal cancer with liver metastasis. Cancer Med. (2017) 6:2850-7. doi: 10.1002/cam4.1241

78. Zhang D, Zhao L, Zhou P, Ma H, Huang F, Jin M, et al. Circulating tumor microemboli (CTM) and vimentin + circulating tumor cells (CTCs) detected by a size-based platform predict worse prognosis in advanced colorectal cancer patients during chemotherapy. Cancer Cell Int. (2017) 17:6. doi: 10.1186/s12935-016-0373-7

79. Hinz S, Hendricks A, Wittig A, Schafmayer C, Tepel J, Kalthoff H, et al. Detection of circulating tumor cells with CK20 RT-PCR is an independent negative prognostic marker in colon cancer patients - a prospective study. BMC Cancer. (2017) 17:53. doi: 10.1186/s12885-016-3035-1

80. Bork U, Rahbari NN, Scholch S, Reissfelder C, Kahlert C, Buchler MW, et al. Circulating tumour cells and outcome in non-metastatic colorectal cancer: a prospective study. Br J Cancer. (2015) 112:1306-13. doi: 10.1038/bjc.2015.88

81. Sotelo MJ, Sastre J, Maestro ML, Veganzones S, Vieitez JM, Alonso $\mathrm{V}$, et al. Role of circulating tumor cells as prognostic marker in resected stage III colorectal cancer. Ann Oncol. (2015) 26:535-41. doi: 10.1093/annonc/mdu568

82. Seeberg LT, Waage A, Brunborg C, Hugenschmidt H, Renolen A, Stav I, et al. Circulating tumor cells in patients with colorectal liver metastasis predict impaired survival. Ann Surg. (2015) 261:164-71. doi: 10.1097/SLA.0000000000000580

83. Musella V, Pietrantonio F, Di Buduo E, Iacovelli R, Martinetti A, Sottotetti E, et al. Circulating tumor cells as a longitudinal biomarker in patients with advanced chemorefractory, RAS-BRAF wild-type colorectal cancer receiving cetuximab or panitumumab. Int J Cancer. (2015) 137:1467-74. doi: 10.1002/ijc.29493

84. van Dalum G, Stam GJ, Scholten LF, Mastboom WJ, Vermes I, Tibbe AG, et al. Importance of circulating tumor cells in newly diagnosed colorectal cancer. Int J Oncol. (2015) 46:1361-8. doi: 10.3892/ijo.2015.2824 
85. Kuboki Y, Matsusaka S, Minowa S, Shibata H, Suenaga M, Shinozaki E, et al. Circulating tumor cell (CTC) count and epithelial growth factor receptor expression on CTCs as biomarkers for cetuximab efficacy in advanced colorectal cancer. Anticancer Res. (2013) 33:3905-10.

86. Gazzaniga P, Raimondi C, Gradilone A, Biondi Zoccai G, Nicolazzo C, Gandini O, et al. Circulating tumor cells in metastatic colorectal cancer: do we need an alternative cutoff? J Cancer Res Clin Oncol. (2013) 139:1411-6. doi: 10.1007/s00432-013-1450-0

87. Sastre J, Maestro ML, Gomez-Espana A, Rivera F, Valladares M, Massuti B, et al. Circulating tumor cell count is a prognostic factor in metastatic colorectal cancer patients receiving first-line chemotherapy plus bevacizumab: a Spanish Cooperative Group for the Treatment of Digestive Tumors study. Oncologist. (2012) 17:947-55. doi: 10.1634/theoncologist.2012-0048

88. Matsusaka S, Suenaga M, Mishima Y, Kuniyoshi R, Takagi K, Terui Y, et al. Circulating tumor cells as a surrogate marker for determining response to chemotherapy in Japanese patients with metastatic colorectal cancer. Cancer Sci. (2011) 102:1188-92. doi: 10.1111/j.1349-7006.2011.01926.x

89. Iinuma H, Watanabe T, Mimori K, Adachi M, Hayashi N, Tamura J, et al. Clinical significance of circulating tumor cells, including cancer stem-like cells, in peripheral blood for recurrence and prognosis in patients with Dukes' stage B and C colorectal cancer. J Clin Oncol. (2011) 29:1547-55. doi: $10.1200 /$ JCO.2010.30.5151

90. Tol J, Koopman M, Miller MC, Tibbe A, Cats A, Creemers GJ, et al. Circulating tumour cells early predict progression-free and overall survival in advanced colorectal cancer patients treated with chemotherapy and targeted agents. Ann Oncol. (2010) 21:1006-12. doi: 10.1093/annonc/mdp463

91. Cohen SJ, Punt CJ, Iannotti N, Saidman BH, Sabbath KD, Gabrail NY, et al. Relationship of circulating tumor cells to tumor response, progression-free survival, and overall survival in patients with metastatic colorectal cancer. $J$ Clin Oncol. (2008) 26:3213-21. doi: 10.1200/JCO.2007.15.8923

92. Yang C, Wei C, Wang S, Han S, Shi D, Zhang C, et al. Combined features based on preoperative controlling nutritional status score and circulating tumour cell status predict prognosis for colorectal cancer patients treated with curative resection. Int J Biol Sci. (2019) 15:1325-35. doi: 10.7150/ijbs.33671

93. Zou K, Yang S, Zheng L, Wang S, Xiong B. Prognostic role of the circulating tumor cells detected by cytological methods in gastric cancer: a metaanalysis. Biomed Res Int. (2016) 2016:2765464. doi: 10.1155/2016/2765464

94. Alix-Panabieres C, Pantel K. Challenges in circulating tumour cell research. Nat Rev Cancer. (2014) 14:623-31. doi: 10.1038/nrc3820
95. Hinz S, Roder C, Tepel J, Hendricks A, Schafmayer C, Becker T, et al. Cytokeratin 20 positive circulating tumor cells are a marker for response after neoadjuvant chemoradiation but not for prognosis in patients with rectal cancer. BMC Cancer. (2015) 15:953. doi: 10.1186/s12885-015-1989-z

96. Kubisch I, de Albuquerque A, Schuppan D, Kaul S, Schaich M, Stolzel U. Prognostic role of a multimarker analysis of circulating tumor cells in advanced gastric and gastroesophageal adenocarcinomas. Oncology. (2015) 89:294-303. doi: 10.1159/000437373

97. Magni E, Botteri E, Ravenda PS, Cassatella MC, Bertani E, Chiappa A, et al. Detection of circulating tumor cells in patients with locally advanced rectal cancer undergoing neoadjuvant therapy followed by curative surgery. Int J Colorectal Dis. (2014) 29:1053-9. doi: 10.1007/s00384-0141958-z

98. Mishima Y, Matsusaka S, Chin K, Mikuniya M, Minowa S, Takayama $\mathrm{T}$, et al. Detection of HER2 amplification in circulating tumor cells of HER2-negative gastric cancer patients. Target Oncol. (2017) 12:341-51. doi: 10.1007/s11523-017-0493-6

99. Tang L, Zhao S, Liu W, Parchim NF, Huang J, Tang Y, et al. Diagnostic accuracy of circulating tumor cells detection in gastric cancer: systematic review and meta-analysis. BMC Cancer. (2013) 13:314. doi: 10.1186/1471-2407-13-314

100. Lee AW, Lin FX, Wei PL, Jian-Wei G, Chen JK. Binary-blend fibberbased capture assay of circulating tumor cells for clinical diagnosis of colorectal cancer. J Nanobiotechnol. (2018) 16:4. doi: 10.1186/s12951-0170330-1

101. Chen CJ, Sung WW, Chen HC, Chern YJ, Hsu HT, Lin YM, et al. Early assessment of colorectal cancer by quantifying circulating tumor cells in peripheral blood: ECT2 in diagnosis of colorectal cancer. Int J Mol Sci. (2017) 18:743. doi: 10.3390/ijms18040743

Conflict of Interest: The authors declare that the research was conducted in the absence of any commercial or financial relationships that could be construed as a potential conflict of interest.

Copyright (c) 2019 Yang, Chen, Wang and Xiong. This is an open-access article distributed under the terms of the Creative Commons Attribution License (CC BY). The use, distribution or reproduction in other forums is permitted, provided the original author(s) and the copyright owner(s) are credited and that the original publication in this journal is cited, in accordance with accepted academic practice. No use, distribution or reproduction is permitted which does not comply with these terms. 